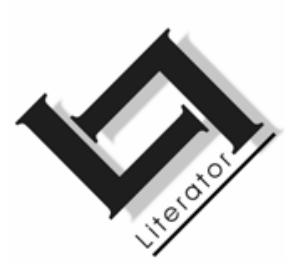

\title{
Kinder- en jeugtoneel in Afrikaans: oorsig en tendense
}

\author{
J.L. (Johan) Coetser \\ Departement Afrikaans en Algemene Literatuurwetenskap \\ UNISA \\ PRETORIA
}

E-pos: coetsjl@unisa.ac.za

\begin{abstract}
Children's and youth theatre in Afrikaans: Overview and trends

This article consists of two main parts. The first part provides a historical overview of children's and youth theatre in Afrikaans, followed by the identification of some trends associated with this form of theatre. The initial aim of the article is to supplement current brief overviews of children's and youth theatre and then to postulate that the same social, political and economic influences are present in children's and youth theatre as in theatre intended for adult audiences. The discussion concludes that children's and youth plays in Afrikaans, notably those published after 1922, offer indications of realities that playwrights, audiences and readers of these plays were confronted with.
\end{abstract}

\section{Opsomming}

Kinder- en jeugtoneel in Afrikaans: oorsig en tendense

Die artikel bestaan uit twee hoofafdelings, waarin eerstens 'n historiese oorsig gegee word van die ontwikkeling van kinder- en jeugtoneel in Afrikaans, gevolg deur die identifisering van 'n aantal tendense met betrekking tot hierdie toneelvorm. Die doel met die bespreking is om bestaande, kort oorsigte van die Afrikaanse kinderen jeugtoneel aan te vul en om aan te toon dat dieselfde sosiale, politieke en ekonomiese kragte in kinder- en jeugtoneel werksaam is as in volwassenetoneel. In die bespreking word tot die gevolgtrekking gekom dat kinder- en jeugdramas wat veral na 1922 in Afrikaans gepubliseer is, 'n aanduiding bied van die werklikhede waarmee dramaturge, gehore en lesers gekonfronteer is. 


\section{Inleiding}

Ten spyte van die feit dat 'n groot aantal primêre tekste bestaan, is dit opvallend dat min navorsing oor kinder- en jeugtoneel $\mathbf{1}$ in Afrikaans gepubliseer is. Tot op hede bestaan daar nog geen studie wat die Afrikaanse kinder- en jeugtoneel volledig vanaf sy ontstaan dek nie. ${ }^{2}$

'n Aantal besprekings as onderafdelings van boekartikels bestaan wel, soos dié deur Le Roux (1986) of Lohann (1988). Steenberg (1983; 1985) verwys in twee kort Klasgids-artikels na kindertoneel, terwyl die gebruik van toneel in die onderwys aandag ontvang van onder andere De Kock (1987), Lombard (1974) en Louw (1965).

Omvattende versamelings kinder- en jeugdramatekste is beskikbaar by NALN (Nasionale Afrikaanse Letterkundige Museum en Navorsingsentrum) en in die Nasionale Toneelbiblioteek - albei in Bloemfontein. DALRO (Dramatiese, Artistieke en Letterkundige Regte-organisasie) se versameling in Johannesburg is ' $n$ aanvulling tot die versameling kinder- en jeugdramatekste.

NALN se F.C.L. Bosman-knipselversameling van berigte oor toneel strek tot ongeveer 1980, maar is nie volledig ontsluit nie. Daarteenoor is die Nasionale Toneelbiblioteek se versameling tekste in 'n reeks katalogusse ontsluit, waarvan die basiskatalogus in 1986 verskyn het (Nasionale Toneelbiblioteek, 1986). Ook ISKEMUS (Inligtingsentrum vir Kinderlektuur en -Media van die Universiteit van Stellenbosch) gee aandag aan kinder- en jeugtoneel, alhoewel die klem eintlik op die opleiding van inligtingkundestudente val (vgl. ISKEMUS, s.j. en Van Tonder, s.j.).

'n Rede vir die beperkte aandag wat Afrikaanse kinder- en jeugdramas tot op hede ontvang het, hou verband met die verspreidheid en, in sommige gevalle, die bekombaarheid en toeganklikheid van tekste en inligting oor tekste. 'n Verdere

1 In die bespreking verwys die terme drama na gepubliseerde (in die wydste betekenis van die woord) dramatekste, teater na drama-in-opvoering, terwyl toneel as 'n sambreelterm vir albei dien.

2 Vergelyk in Engels Greyvenstein (1988) se proefskrif The history and development of children's theatre in English in South Africa en Patricia Storrar (1968) se Beginners please: A history of the Children's Theatre in South Africa. Vergelyk ook Greyvenstein se artikel "Let us entertain you! Children's theatre and popular entertainment" (Greyvenstein, 1989). 
belemmering is die afwesigheid van 'n omskrywing van watter toneeltekste as kinder- en jeugtoneel kwalifiseer. ${ }^{3}$

Hierdie artikel poog nie primêr om probleme wat verband hou met 'n omskrywing van die inhoud en betekenis van die begrip kinder- en jeugtoneel uit te stryk nie. In navolging van Hunt (1991:60; aangehaal in voetnoot 3 ) word van bestaande indelings gebruikgemaak om tendense in kinder- en jeugtoneel te probeer uitwys. Wat op grond van genoemde bronne na vore tree, is dat die betekenis van die term met verloop van tyd verander het. 'n Verklaring vir dié verandering is dat die begrip verruim het, omdat kinder- en jeugtoneeltekste, soos ander vorme van kinder- en jeugliteratuur, aan grensoorskrydings onderhewig is.

Die artikel bestaan uit twee hoofafdelings: eerstens word 'n historiese oorsig gegee van die ontwikkeling van kinder- en jeugtoneel in Afrikaans; daarna volg ' $n$ identifisering van ' $n$ aantal tendense wat op hierdie toneelvorm betrekking het. Die doel met die artikel is om die bestaande, kort oorsigte van die Afrikaanse kinderen jeugtoneel aan te vul en om aan te toon dat dieselfde sosiale, ekonomiese en politieke kragte as in volwassenetoneel ook in kinder- en jeugtoneel werksaam is.

\section{Historiese oorsig}

\subsection{Teater}

Die kommersiële en opvoedkundige kinder- en jeugteater neem in die Suid-Afrikaanse teatersisteem 'n geringe plek in. Kinder- en jeugteater in Afrikaans ontvang geen finansiële ondersteuning van die formele sektor nie. Meestal word kinder- en jeugteater sporadies ondersteun vanuit die private sektor. Permanente toneelgeselskappe kan in Suid-Afrika nie 'n bestaan maak uit die opvoering van kinder- en jeugteater nie.

Die sporadiese ondersteuning van jeugteater vind hoofsaaklik plaas gedurende belangrike vakansiefeestye of tydens kunstefeeste, soos die Klein Karoo Nasionale Kunstefees in Oudtshoorn of die

3 Die probleem om 'n algemeen geldige omskrywing van die begrip kinder- en jeugtoneel te vind stem ooreen met die probleem om 'n algemeen geldige omskrywing van die term kinder- en jeugliteratuur te vind (Ghesquiere, 1995:910). Peter Hunt (1991:60) kom tot die volgende gevolgtrekking: "We define children's literature, then, according to our purposes - which, after all, is what all definitions do: they divide the world according to our needs." 
Aardklopfees in Potchefstroom. Toneelfeeste wat spesifiek vir kinder- en jeugteater voorsiening maak, sluit die volgende in: die Logan Toneelfees, die Montagu Toneelfees of die ATKV se Tienertoneelkompetisie. Alhoewel baie kinder- en jeugteatertekste by hierdie feeste opgevoer word, word min tekste gepubliseer. Ander oorwegings speel ook ' $n$ rol in die beskikbaarheid van gepubliseerde tekste.4 Volgens Greyvenstein (1988:215) dra sommige akteurs se opvatting dat die vertolking van rolle in kinderen jeugteater nie gelykgestel kan word aan rolle voor 'n volwassenegehoor nie, onder andere tot dié geringskatting by.

' $n$ Verdere oorweging is die agterstand wat klassieke kinder- en jeugteater oor jare in skole opgebou het. Finansiële en opvoedkundige oorwegings bepaal meermale die formaat van skoolaanbiedings, met die gevolg dat kinder- en jeugteater as sodanig nie tot sy reg kom nie. In plaas daarvan geniet gemengde vorme, soos operettes en revues voorkeur, omdat die meeste leerlinge betrek kan word en die oorwig ouers dié opvoerings as betalende gehoor sal bywoon.

Naas die stimulus wat wel van skoolproduksies uitgaan, lewer die dramadepartemente van universiteite, technikons en in sommige gevalle, onderwyskolleges 'n verdere bydrae tot die bevordering van kinder- en jeugteater. Hul bydrae is gewoonlik in die vorm van spraak-en-drama-opleiding vir studente en die opvoer van kinder- en jeugstukke wat met hierdie opleiding verband hou.

Professionele geselskappe se opvoerings van Afrikaanse kinder- en jeugstukke het vanaf die sestigerjare afgeneem. Die jeuggeselskap van 'n streekkunsteraad soos KRUIK (Kaaplandse Raad vir die Uitvoerende Kunste) het aanvanklik 'n groot bydrae gelewer om kinder- en jeugteater in Afrikaans onder leerlinge bekend te stel. In Natal het NARUK (Natalse Raad vir die Uitvoerende Kunste) nie 'n Afrikaanse jeuggeselskap gehad nie en hierdie funksie is gedeeltelik vervul deur die dramadepartement van die Durbanse Onderwyskollege (DOK).

$4 \quad$ In hierdie artikel val die klem op gepubliseerde dramatekste. Omdat dramatekste opvoeringsgerig is, met ander woorde aanwysings vir die opvoer daarvan bevat, word in die bespreking enkele kere na opvoerings verwys. Die opvoer van kinder- en jeugteater in Afrikaans is 'n onderwerp wat afsonderlike bespreking, selfs 'n uitgebreide studie, sou kon regverdig. 
Ten opsigte van die streekkunsterade het KRUIK 'n baanbrekersrol vervul (Greyvenstein, 1988:86, 93-94). KRUIK se voorloper, die NTO (Nasionale Toneelorganisasie), is in 1947 gestig. Veral vanaf 1959 het die NTO toneelprogramme saamgestel wat tydens toere by skole opgevoer is - totdat hierdie funksie teen 1963 deur KRUIK oorgeneem is. Programme vir laerskole het by spesifieke vakinhoude aangesluit en in hoërskole by voorgeskrewe boeke veral die dramatekste vir die vakke Afrikaans en Engels.

Private produksiehuise of groepe het ook kinder- en jeugteater opgevoer, maar het nie uitsluitlik op hierdie genre gekonsentreer nie. Voorbeelde hiervan is Carel Trichardt en Petru Wessels se Teaterhuisie in Pretoria, die Breugel-toneelgroep op Stellenbosch, of die BAT-kinderteater (Bellville Afrikaanse Toneelvereniging-kinderteater). Die ATKV bied reeds vanaf 1963 'n amateurtoneelfees aan wat verskeie groeipunte opgelewer het: onder andere 'n skoletoneelfees, regisseurskursusse, Kampustoneel (vir tersiêre studente) en 'n herfsskool vir dramaturge. In 1989 het dié organisasie 'n bundel gepubliseer met die vyf beste eenakters wat tydens skoletoneelfeeste opgevoer is, naamlik Tienertoneel. $\mathbf{5}$

Die opbloei van kinder- en jeugteater in Afrikaans tydens die sestigerjare kan daaraan toegeskryf word dat Afrikaanse teater deur die staat gesubsidieer is. Daarna het die streekkunsterade se subsidies afgeneem en het die aantal opvoerings gevolglik afgeneem. Tog is kinder- en jeugdramatekste steeds in die tagtigeren negentigerjare gepubliseer. Hierdie situasie stem ooreen met die situasie aan die begin van die twintigste eeu. Toe was daar nog nie sprake van 'n formele Afrikaanse opvoeringskonteks soos wat die NTO of die streekkunsterade later sou bied nie.

\subsection{Drama}

\section{Die taalstryd as agtergrond}

Die eerste opvoering van 'n Afrikaanse toneelstuk vir volwassenes het ná 1860 in 'n private woning op Daljosafat naby die Paarl plaasgevind. Die eerste opvoerings van 'n Afrikaanse toneelstuk vir 'n jong gehoor het eers ongeveer dertig jaar daarna gevolg

5 As gevolg van die groot getal verwysings na primêre tekste is volledige bibliografiese besonderhede nie in die lys verwysings aan die einde opgeneem nie. Dié besonderhede kan wel in die volgende bronne nagegaan word: Lohann (1988), Nasionale Toneelbiblioteek (1986; 1987; 1988; 1992; 1994; 1999) en Senekal en Van Aswegen (1980). 
(Bosman, 1942:v-vii). J.H.H. de Waal, wat onder die skuilnaam Janni geskryf het, was een van die eerste dramaturge van stukke vir 'n kinder- of jeuggehoor. ' $n$ Voorbeeld is ' $n$ Les oor di tier wat hy in 1892 geskryf het terwyl hy 'n onderwyser op Uitenhage en Utrecht was (Binge, 1969:17). Hierdie toneelstuk is "'n [g]rappige stuk om opgevoer te word deur jongetjies" en "[d]i persone bestaan uit di onderwijser en 7 jongetjies" (Janni, 1942:20).

Omdat De Waal se stukke geskryf is vir opvoering voor die plaaslike Debats- en Christelike Jongeliedevereniging, was die opvoeringskonteks geslote. Daar was dus nie, soos in die geval van SuidAfrikaanse kinder- en jeugtoneel in Engels (Greyvenstein, 1988:98), sprake van beïnvloeding deur die pantomime of sirkus, sprokies en ander nietoneeltekste, prosa én poësie, nie. Hierdie invloede sou eers later in die Afrikaanse kinder- en jeugdrama volg, onder andere in Maxie de Villiers en De Wet Laubscher se tweetalige werk Die sirkus wat in die dertigerjare van die twintigste eeu gepubliseer is, Die skone slaapster van Rikie Postma (1937), Stephanie en Talitha C. Faure se verwerking van Rikie Postma se verhaal Elsie die veldkindjie (1921), of meer onlangs, Verna Vels en W.O. Kühne se verwerking van hul Liewe Heksie- en Huppel-verhale tot toneelstukke in die bundel Met Huppel en Liewe Heksie op die planke (1984), asook die opvoerings of verwerkings van Barrie Hough se Vlerkdans (1999), Skilpoppe (2000) en Breek (2001).

Dit is belangrik dat De Waal sy 'n Les oor di tier geskryf het as 'n bydrae tot die taalstryd tydens die periode van die Eerste Afrikaanse Taalbeweging. Dat dit in Afrikaans geskryf en vir die eerste keer juis voor die Uitenhaagse Debats- en Christelike Jongeliedevereniging opgevoer is, móés dus tot die geslotenheid van die opvoeringskonteks bygedra en 'n ideologiese ondertoon aan die opvoering gegee het. Dat Bosman (1968:26) die eerste kinderdrama in Afrikaans dus eers in 1921 plaas met die publikasie van M.E. Rothmann se sangspel, Die mieliedogter is opvallend, maar nie onverwags nie. Vir Bosman (1968:26) was Die mieliedogter die eerste "egte kinderstuk" in Afrikaans, omdat dit "[...] aanpas by die kindersiel, wat hom rig op artistieke ontwikkeling van die kindersmaak en kinderverbeelding en nie die oumensagtige sedeprekerigheid van voorheen bring nie".

\section{Die Suid-Afrikaanse Oorlog as agtergrond}

Die aanloop en nagevolge van die Suid-Afrikaanse Oorlog (AngloBoereoorlog, 1899-1902) het bygedra tot die opvallende tydsverloop - ongeveer veertig jaar - tussen die eerste opvoerings van Die les 
oor di tier en die publikasie van Die mieliedogter. Die Eerste Taalbeweging het teen die vorige eeuwending begin doodloop en Afrikanernasionalisme was een van die gevolge van die SuidAfrikaanse Oorlog. Die Afrikanernasionale beweging het uiteindelik 'n breë kultuur-politieke beweging geword, wat veral as gevolg van die totstandkoming van Afrikaanse uitgewerye en finansiële instellings, geleenthede geskep het vir die publikasie van kinder- en jeugliteratuur in Afrikaans. In hierdie verband beweer Le Roux (1986:7) dat min skoolbiblioteke teen 1930 meer as vyftien boeke besit het en dat daar in 1922 slegs ongeveer vyf-en-twintig Afrikaanse kinderboeke bestaan het.

Die publikasie van P. Retief Gauché se stukkie Wie die skuldige is (in die bundel Twaalf samesprake - 1918), moet beskou word as 'n mylpaal. Alhoewel Wie die skuldige is as gevolg van die Regter se stereotiepe optrede en in terme van Bosman (1968:26) se maatstaf kwalik as 'n egte kinderdrama kwalifiseer, is die waarde daarvan daarin geleë dat dit geskryf is met die doel dat skoolkinders dit kan opvoer by die afskeid van 'n onderwyser. In 'n latere bundel, Samesprake vir skoolkinders (s.j.), skryf Gauché hoofsaaklik vanuit die perspektief van kinder- en jeugpersonasies en meestal met die skoollewe as agtergrond.

\section{Sosiaal-gedrewe jeugdramas}

Die ontstaan van kinder- en jeugdramas in Afrikaans was in die geval van De Waal hoofsaaklik sosiaal gedrewe en in die geval van Gauché 'n gevolg van 'n behoefte wat vanuit die onderwys gevoed is. Met verloop van tyd sou hierdie behoefte groei namate Afrikaners, veral vanaf die vyftigerjare, meer vermoënd en geletterd geword het en skoolplig vir blanke kinders ingestel is. Die vroegste kinderdramas was dus ten nouste verbonde aan die sosiomaatskaplike, politieke, ekonomiese en opvoedkundige agtergrond van die Afrikaner. Soos De Waal (tydens die Eerste Afrikaanse Taalbeweging) het Gauché (in 'n periode van Britse kulturele imperialisme) teen die agtergrond van 'n taalstryd geskryf, maar hul politieke kontekste het verskil.

\section{Ontwikkelings in die buiteland}

Greyvenstein (1988:23 e.v.) wys verder op die invloed wat van ontwikkelings in die buiteland, spesifiek Brittanje, in die twintiger- en dertigerjare uitgegaan het. In hierdie verband was Peter Slade se opvattings besonder invloedryk - vanweë sy beklemtoning dat dramas vir bepaalde ouderdomsgroepe geskryf moet word en dat 
jong toeskouers by die handelingsvoorstelling in die speelruimte betrek behoort te word.

'n Gevolg van Slade se gedagtes was dat die onderskeid tussen kinder- en jeugdramas vroeg in Afrikaans na vore getree het. In 1933 verskyn Die sleutel en vier ander toneelstukkies van J.G. Gauché met die onderskrif "veral geskik vir skoolkonserte". Daarin verskyn stukke "vir kleiner kinders" (In droomland en Kabouterkoning) en "vir groter kinders" (Haar deeltjie bygedra, Die sleutel en Japie). Ten opsigte van kinderdramas kom die element van fantasie reeds voor, maar die tekste "vir groter kinders" staan steeds onder buitelandse invloed of kom naïef voor - vergelyk die teenwoordigheid van 'n koning, howelinge of koningskneg in Haar deeltjie bygedra of die oordrewe voorstelling van kwajongstreke in Japie. Dit word aangedui dat Haar deeltjie bygedra "vir groter kinders" geskryf is - na aanleiding van die gedig "The two churchbuilders" deur J.G. Saxe.

\section{Die vyftigerjare: veranderende politieke en maatskaplike situasie}

Die vyftigerjare het ' $n$ keerpunt in die Afrikaanse kinder- en jeugdrama ingelei. Die opkoms van 'n Afrikanermiddelklas, die nuwe Nasionale Party-regering se algemene bemiddeling ten gunste van Afrikaans en die toenemende aandag van toneelgeselskappe, soos die NTO en die latere streekkunsterade, het daartoe gelei dat die Afrikaanse kinder- en jeugdrama begin groei het. Hierdie verskynsel is waarneembaar in die getal publikasies deur enkeldramaturge, maar veral ook in die publikasie van dramaversamelbundels wat die mark vir skole voorgeskryf het.

Vanaf 1952 verskyn daar minstens drie reekse, naamlik Prettige praatstories vir voordrag en dramatisering deur A.K. Bot, Hettie Cillié en J.J. van Tonder, saamgestel vir gebruik vanaf die grade/ substanderds tot standerd 5; Woord en daad: gegradeerde toneelstukkies en samesprakies deur die APB-komitee (Afrikaanse Pers Boekhandel-komitee) vir Skoolboeke saamgestel vir gebruik in standerds 1 en 2, en verder tot standerds 7 en 8; en vanaf 1954 Die junior akteur - ook deur die APB-komitee vir Skoolboeke, saamgestel vir gebruik in standerds 1 tot 5 .

\section{Uitgewers kry 'n greep op die voorskryfmark}

Hiermee het 'n tendens na vore getree wat oor die volgende aantal dekades sou voortduur, naamlik dat een of meer hoofstroomuitgewersmaatskappye of hul vertakkings 'n greep op die skool- 
voorskryfmark sou verkry. Dié tendens moet, volgens Steenberg (1983:12, 16), ook beskou word as 'n aanvanklike poging om die posisie van spesifiek die Afrikaanse kinder- en jeugdrama binne die Suid-Afrikaanse literêre, en in die besonder die dramasisteem, te versterk.

Vergelyk in hierdie verband die prominente plek wat Gerhard J. Beukes en Temple Hauptfleisch as samestellers van bundels kinderen jeugdramas verwerf het. Voorbeelde hiervan is Beukes se versameling eenbedrywe Twee sente vir 'n pêrel (1968), wat as nommer 3 in die Van Schaik-toneelreeks gepubliseer is, of ' $n$ Lag en 'n traan (Van Schaik, 1988). Nog voorbeelde van versamelbundels uit die sestiger- tot negentigerjare is Ettie Bierman se Monoloë, samesprake en toneelstukkies (Van Schaik, 1969), P.J. du Toit en Temple Hauptfleisch se Voetlig 1 (De Jager-HAUM, 1983) en Voetlig 2 (De Jager-HAUM, 1983), Die spieël en die weerkaatsing van Temple Hauptfleisch (Academica, 1985), die ATKV se Tienertoneel (Tafelberg, 1989), P.J. du Toit se Jeugpret (Academica, 1992), Die magiese kring van Temple Hauptfleisch en Herman Pretorius (Jutalit, 1991), asook Van die banke op die planke deur Elise van Wyk (Out of Africa, 1994). Daarteenoor is Boomhuis, droomhuis en ander eenbedrywe (1981) deur Temple Hauptfleisch en Jan Taljaard gepubliseer deur die minder bekende uitgewer, Pat Lubbe. George Weideman se versamelbundel Alles op die spel (Klipbok, 1991) het ook nie by 'n hoofstroom-Afrikaanse uitgewer verskyn nie

\section{Die sewentigerjare: buitetekstuele veranderinge}

Vanaf die tweede helfte van die sewentigerjare het die gewildheid van gepubliseerde kinder- en jeugdramas afgeneem. Dié afname kan toegeskryf word aan veranderinge wat met die buitetekstuele agtergrond verband hou: aspekte soos die toenmalige politieke bedeling, die uitgewersbedryf, die opset van die streekkunsterade en die skolestelsel het bygedra tot die gewildheidsafname. Anders as in die geval van prosawerke, het die teater se veranderende konteks, gekoppel aan sy openbare en gemeenskapsaard, die afname in dié genre se gewildheid versnel.

Elsabe Steenberg $(1983: 12,16)$ merk tereg op:

'n Mens wonder of 'n kragtige stimulus ontbreek om toneelskrywers aan te spoor om nie net goeie kindertonele te skryf nie maar dit ook te laat publiseer? [...] Het die tyd nie aangebreek dat 'n uitgewer 'n wedstryd moet uitskryf om dié genre te stimuleer nie? 
Daar was voor én na Steenberg se oproep wel pogings "om dié genre te stimuleer". Benewens tekste wat in die gewone gang van sake geskryf of deur bemiddeling van 'n liggaam soos die ATKV versamel en gepubliseer is (soos die vyf tekste opgeneem in Tienertoneel, 1989), is nuwe dramas geskryf vir dramakompetisies, of is tekste in Afrikaans vertaal.

Naas verwerkings het vertaalde kinder- en jeugtekste die Afrikaanse drama van vroeg af verryk. In 1952, byvoorbeeld, verskyn 'n vrye vertaling en verwerking van Prosper Merimee se Mateo Falcone deur Jaco van der Merwe. Veel bekender is Nerina Ferreira se vertalings uit Engels in die bundels Jeugteater 1, Jeugteater 2 en Jeugteater 3. Hierdie reeks, gepubliseer in 1977, was so gewild in die skoolvoorskryfmark, dat Jeugteater 3 in 1990 reeds 'n agste druk beleef het.

\section{Die tagtigerjare en daarna}

Vanaf die tweede helfte van die tagtigerjare het die aanvraag vir nuwe dramatekste vanuit die skoolvoorskryfmark baie afgeneem. Vertaalde tekste het steeds die lig gesien en is deur hoofstroomuitgewers, DALRO en die Nasionale Toneelbiblioteek gepubliseer. In 1996 gee DALRO Die geklike deurmekaarspul eiland van dr. Moron uit. Dié teks is Kobus Strydom se vertaling van Tim Kelly se verwerking van The island of Dr. Moreau deur H.G. Wells. Slawomir Mrozek se Out at sea, is as Vlot ter see vertaal deur die Universiteit van Stellenbosch se dramadepartement en het in 1997 by die Nasionale Toneelbiblioteek verskyn.

Benewens geleentheidstekste wat met die oog op die viering van die Van Riebeeckfees in 1952 geskryf is, publiseer Pieter-Dirk Uys ook in 1985 die jeuggeleentheidsdrama Skote! (wat reeds in 1976 geskryf is). Piet Boonzaier weer publiseer in 1993 die libretto van die kinderoperette Charlie se sirkus. Laasgenoemde is die wenstuk van 'n dramakompetisie wat in 1990 deur die organisasie Jong Dames Dinamiek uitgeskryf is en sluit onder andere die liedjie "Tsolo wamtini", met die volgende refrein, in:

Haya wênina.

Haya wênina.

Tsolo wamtini, tsolo wamtini,

Pôkô ham, ham, ham. ${ }^{6}$

6 'n Baie vrye vertaling is: "Haai jy! / Haai jy! / Tsolo, wat het jy aan hom gedoen? Tsolo, wat het jy aan hom gedoen? / Rook hmmm, hmmm, hmmm." 
Die insluiting van nie-Afrikaanse elemente in die libretto gee 'n aanduiding van die veranderende aard en multikulturele samestelling van Afrikaanse laerskole na 1994.

Pieter-Dirk Uys het sy drama Skote! in 1976 op versoek van Esther van Ryswyk geskryf om opgevoer te word ter herdenking van die vyftigjarige bestaan van die Hoërskool Jan van Riebeeck (Kaapstad). Die teks trek drie vlakke saam: Van Riebeeck se koms aan die Kaap, gedeeltes van die akteur-leerlinge se persoonlike lewensgeskiedenis en brokkies aktualiteit. Groot politieke onrus het vanaf 1976 - na die eerste opvoering van die teks op 22 April - in veral skole uitgebreek. Volgens Van Ryswyk (1985:ii), het die dramaturg die spelers en die gehoor met hierdie stuk sensitief probeer maak vir die politieke aktualiteit.

\section{Tendense}

Indien tekstuele en buitetekstuele invloede op die ontwikkeling van die Afrikaanse kinder- en jeugdrama in aanmerking geneem word, is dit moontlik om 'n aantal breë periodes te onderskei waarin temas en tendense afsluit, mekaar oorvleuel of voortgesit is.

\subsection{Tendense in jeugdramas tot en met die sestigerjare}

\section{Grense nie altyd duidelik nie}

Soos Henriette Grové (Na honderd jaar, 1952), Corlia Fourie (My aaklige jonger sussie, 1991) en andere het sowel P. Retief Gauché en Japie Heese vanaf die twintigerjare van die vorige eeu ook volwassene- én kinder- en jeugdramas geskryf (vgl. Senekal \& Van Aswegen, 1980:35, 41). Die grens tussen stukke vir volwassenes, kinders en jeugdiges is egter nie altyd duidelik in Gauché en Heese se oeuvres nie.

In Gauché se bundel Twaalf samesprake (1921) verskyn byvoorbeeld die toneel Hoe Koos aansluit by die debatsvereniging. Daarin probeer Sannie om Koos by die debatsvereniging te laat aansluit, maar sy verskoning is dat hy nie die tyd daarvoor het nie, aangesien hy jukskeie moet maak. Al maak moderne jong volwassenes nie meer jukskeie nie, gee hulle dramatiese alter ego's 'n voorstelling van grensoorskrydende, eietydse kwessies wat vir jeugdiges en jong volwassenes ter sake is. Dink in hierdie verband aan personasies soos Koos in genoemde toneel en die personasies in die latere verhoogverwerkings van Hough se prosawerke 
Vlerkdans (1999), Skilpoppe (2000) en Breek (2001), of in Kobus Strydom se kabaret Hoe's dit, my ou? (1989).

\section{Die kultuur-historiese en politieke agtergrond van die periode}

Gauché se voorstelling van 'n kultuurlewe waarin 'n debatsvereniging 'n belangrike plek inneem (Hoe Koos aansluit by die debatsvereniging, 1921), sy stereotipering van 'n Joodse spekulant (Chefnawanskie op die platteland, 1921) of Heese se voorstelling van 'n welvarende gesin in Klein woelwater (1939), verteenwoordig almal kultuur-historiese projeksies van 'n sosio-politieke konteks en die onderliggende ideologie van Afrikanernasionalisme. In Hoe Koos aansluit by die debatsvereniging (1921) verklaar Sannie byvoorbeeld: "Baie van ons beste Volksmanne het al erken dat hulle ontsaglik veel te danke het aan die ou Debatsvereniginge van hul jong dae." Vergelyk ook die linguisties-dramatiese stereotipering van die Jood Chefnawanskie (Chefnawanskie op die platteland, 1921) in die volgende spreekbeurt: "Dat was koed biesnies, koed biesnies, al sê hulle die joed hy vernjoek, maar dis maar net biesnies, biesnies hulle verstaan nog nie die biesigheid doen nie."

\section{Kinder en jeugdramas spesifiek afgestem op die Voortrekker- beweging}

'n Aantal skrywers het kinder- en jeugdramas spesifiek vir die Voortrekkerbeweging geskryf. Benewens Japie Heese, met Twaalf toneelstukkies vir Voortrekkers (1941), publiseer U.M. Gerryts in 1937 die bundel Na Vyftig Jaar en ander toneelstukkies vir Voortrekkers en F.J. Weideman Klaas Droster: toneelspel vir Voortrekkers in ses tonele (s.j.). Alhoewel die Voortrekkerbeweging deur die bemiddeling van die F.A.K. (Federasie van Afrikaanse Kultuurvereniginge) deur die volksnasionalistiese Broederbond gestig is (Davenport, 1989:320), tree dié dramas nie as direkte mondstukke van die Broederbond op nie. Die Voortrekkerbeweging se aktiwiteite was deel van 'n breë kulturele diskoers wat in sy teruggryping na die Voortrekkerverlede en na die waardes wat daaruit sou spreek, in dié dramas weerklink. In Weideman se Klaas Droster (s.j.) luister die gehoor na die "Voortrekkerslied" en verneem van die beweging se uniforms en kentekens.

\section{Stereotipering}

Soos in Chefnawanskie op die platteland (1921) word in Klaas Droster ook van stereotipering gebruik gemaak. Kiewiet word deur sy taalgebruik as anders gemerk; sy taal wyk af van die aanvaarde register. ("Maar, baas Piet, ek hy amper versjeet, baas Sarel hy 
gasê, baas Piet hy moet gou kom daar by die plaas".) Hierdie beklemtoning en stereotipering van anderswees as tendens sluit ook aan by Klaas Droster se naam en skaapstelery. In hierdie opsig verteenwoordig sy taalgebruik en optrede - en selfs dié van Jantjie, Droster se handlanger en Kiewiet, oom Piet se veewagter kultureel 'n afwykend-anderse en gemarginaliseerde stem in die Afrikaanse kinder- en jeugdrama. Klaas se dialoog is deurspek met Engelse woorde en hy word in die slot deur die Leeuspan in hegtenis geneem.

\section{Historiese tekste met 'n didaktiese strekking}

Nog voorbeelde van kinder- en jeugdramas met 'n didaktiese strekking is tekste met 'n historiese agtergrond.

Historiese dramas uit die vyftigerjare wat teruggryp na die verlede en die konstruksie van dele van 'n Afrikanermitologie verteenwoordig, is onder andere Ben Conradie se Ons vir jou Suid-Afrika (1952) en Die stigtingsvergadering van die Genootskap van Regte Afrikaners (1952), Henriette Grové se Na honderd jaar (1952) en Wolraad Woltemade (1952) deur J.F. Marais. Met die uitsondering van Conradie (Die stigtingsvergadering van die Genootskap van Regte Afrikaners (1952)) het dié tekste in die Woord en daad-reeks (1952) van die APB-komitee vir Skoolboeke verskyn. Een van die werkwyses waarvan in dié tekste gebruik gemaak word, is om gebeurtenisse uit die dramatiese (en historiese) hede en verlede met mekaar in verband te bring.

In Laubscher se Vooraand Dingaansdag (1936) droom Pieter byvoorbeeld dat hy in Piet Retief se plek in Dingaan se kraal staan en in Na honderd jaar (1952) deur Grové besoek twee lede van die Voortrekkerbeweging oom Koos en tant Liesbet in 1844 op hul grensplaas. In Conradie se stuk Ons vir jou, Suid-Afrika (1952) is die vier personasies kinders van Vryburgers en speel die stuk af in die jaar 1657. 'n Dominante meestersimbool in die Afrikanermitologie kom daarin voor, naamlik dat die Afrikaner vir 'n doel deur God uitgekies is. Vergelyk Cornelius Pieterse se woorde:

[...] maar hoe sal dit oor 300 jaar lyk, in 1952, as ons almal ons plig doen? As ons die land oorwin, dit bewoon en hier 'n regverdige, Christelike beskawing vestig. As ek daaraan dink, dan wens ek dat die ewigheid my vlees telkens wil verjong en my spaar tot die dag waarvan ek gepraat het. [...] Suid-Afrika was eens op 'n tyd God se droom; julle was dit. 


\section{Godsdienstige strekking}

Opmerklik in die vyftigerjare is ook die publikasie van verskeie tekste en versamelbundels met 'n godsdienstige strekking.

Van M. Krige-Esterhuysen en M.C. Bezuidenhout verskyn in 1957 byvoorbeeld die bundel Die saaier: gewyde items vir kinderkonserte. H.E. van Wyk publiseer in 1952 die Kersspel Die blye tyding en in 1956 verskyn die bundel Wit diamante: 'n bundel toneeltjies en samesprake vir opvoerings van die Sondagskool, Kinderkrans, Christelike Jeugverenigings en ook vir die skool. Kenmerkend van Van Wyk se Die blye tyding (1952) is die wyse waarop die personasies 'n herkenbare, tydgenootlike gestalte vertoon. Josef en Maria klop by die "Bethlehem-gashuis" aan, Josef is jammer dat hy nie 'n "donkie" gehuur het nie en die "Gasvrou" is ontevrede omdat haar man, die "Gasheer", vir die twee vreemdelinge plek maak in die stal. Van Wyk sluit in hierdie opsig aan by die onthistorisering (Kannemeyer, 1981:2-7) wat in een van die eerste Kersspele in Afrikaans voorkom, naamlik Die skaapwagters van Betlehem (1941) deur Uys Krige.

Of hierdie dramas wat almal die invloed van spesifieke historiese, politieke, kulturele, godsdienstige en ideologiese faktore weerspieël, wel as kinder- en jeugteater kan deurgaan, is nie altyd duidelik nie. As gevolg van die aard van die teikengehoor en die perspektief van die teks wat nie altyd dié van 'n kind of ' $n$ jeugdige is nie, kom veral die konsep jeugteater, naamlik teater bedoel vir "die jeug", in die gedrang. Soos aangetoon, vervaag die grens tussen toneel vir jong volwassenes en volwasseneteater in sommige gevalle.

\subsection{Tendense in kindertoneel tot en met die sestigerjare}

Nie dieselfde tendense wat in jeugtoneel voorkom, is aantoonbaar in die Afrikaanse kindertoneel van dié periode nie. 'n Verklaring hiervoor is dat 'n kindergehoor vanweë sy aard en ouderdom nie op dieselfde wyse vatbaar is vir die gedagtes en opvattings wat in jeugtoneel voorkom nie.

\section{Fantasie}

Een van die vroegste tendense in die Afrikaanse kindertoneel is die voorkoms van fantasie, waarskynlik omdat dit so 'n belangrike bestanddeel van 'n jong kind se bestaan vorm. Jong kinders en kleuters, beweer Steenberg (1987:15), "weet nie eens baie goed dat daar 'n verskil is tussen werklikheid en fantasie nie: albei word doodnatuurlik ervaar". Sy verduidelik verder dat dit "[...] in kinder- 
fantasie [gaan] om die indirekte vestiging van morele waardes, veral die siening van die goeie wat oor die bose seëvier".

In die Afrikaanse kindertoneel neem fantasie meermale die vorm aan van omwerkings van Europese sprokies, die skep van eie sprokies op die spoor van Europese voorbeelde, folklore of selfs grildramas.

Bekende omwerkers was Japie Heese, Stella Blakemore ('n Wedstryd in Droomland, 1934), Maxie de Villiers en De Wet Laubscher (Kaskenades van Jakkals, 1934), Stephanie en Talitha C. Faure (met hul verwerking van Rikie Postma se 1921-verhaal, Elsie die veldkindjie), Rikie Postma (Die skone slaapster, 1937), Hilda Postma ( $\mathrm{Na}$ towerland/Varkiebroer, s.j.), Hélène de Klerk (Koe-ee, 1940), of Eunice Bosman (Eikenhof se spookvrou, 1952).

Een van die eerste omwerkings is A.J. van Zyl se werk My pa is 'n man (1923), waarvoor die patroon van die Europese sprokie as onderbou dien. Die sosiohistoriese agtergrond is verarming en die trek van blanke mans vanaf die tweede dekade van die twintigste eeu om in myne te gaan werk. Die opset van die stuk stem egter met dié van sprokies soos Hansie en Grietjie ooreen, waarin (wees)kinders oorgelewer word aan die optrede van 'n wrede stiefmoeder of heks, wat later tot verantwoording geroep word. Aan die begin van die eerste bedryf verneem die gehoor dat Kobus en Marie se pa op 'n myn gaan werk het, dat hul ma oorlede is en dat hulle by hul tante moet bly. Sy behandel hulle glad nie goed nie en neem die geld wat hul pa stuur vir haarself. Die Goeie Fee en ses ander feetjies verskyn egter op die verhoog en belowe dat hul pa sal terugkeer.

Die gebruik van fantasie in My pa is 'n man (1923) of in Rikie Postma se Waar die reënboog end (1930) sou in die volgende dekades voortgesit word, onder andere in die werk van Bessie Kotzé (Die stout klein dwergie, 1961), Mariechen Naudé ('n Poppebruilof, 1960), Pieter Bredenkamp (Die skone slaapster, 1971), Lalie Beukes (Sneeuwitjie en die sewe dwergies, 1970), of Verna Vels en W.O. Kühne se Liewe Heksie- en Huppel-stukke. 'n Aantal daarvan is operettes. Teenoor hierdie stukke staan egter die realisme in George Weideman se "weeshuisstuk" Wees (1991).

\section{Die invloed van die magiese element verminder}

In ander dramas ná 1960 oorheers fantasie steeds, maar die invloed van die magiese element neem af. Pieter Fourie se Hansie die hanslam (1970) gaan oor slagter Rondomlelik se pogings om 
Hansie tydens 'n droogte te slag en sy vleis aan die burgemeester se vrou te verkoop. Die karakters vorm twee herkenbare groepe wat Rondomlelik se poging óf ondersteun óf teenstaan. Saam met die fantasie-element, lê die grootste ooreenkoms tussen Hansie die hanslam en sprokies oor die algemeen juis in die duidelike teenoormekaarstelling van strewes. Rondomlelik word deur sy vrou, Liesbet, ondersteun en hulle kom te staan teen Hansie, Oupatjie en Marie, 'n jong skooldogter.

Die fantasie in hierdie stuk berus op die vermenging van primêre en sekondêre werklikhede. Al is Hansie 'n skaap, kan hy praat en is daar by hom selfs sprake van moraliteit:

\begin{tabular}{|c|c|}
\hline Marie & $\begin{array}{l}\text { (Kop deur venster): Hansie, nee. Ek het alles } \\
\text { gehoor. }\end{array}$ \\
\hline Hansie: & $\begin{array}{l}\text { Mê-êêê! Môre, Marie. Maar ek mag tog. Ek is mos } \\
\text { nie 'n mens nie, ek is net 'n skaap. }\end{array}$ \\
\hline Marie: & $\begin{array}{l}\text { Jy's nie net sommer 'n skaap nie. 'n Skaap leef in } \\
\text { die veld en is baie dom. Daarom sê die mense } \\
\text { iemand is so dom soos 'n skaap. Jy bly in 'n huisie } \\
\text { by mense en jy is slim ... jy is 'n aangenome mens. }\end{array}$ \\
\hline
\end{tabular}

Van dié moraliteit maak die dramaturg gebruik om reaksie van sy gehoor te ontlok, soos om vir Hansie kant te kies wanneer hy Rondomlelik van agter stamp. In dié pogings om gehoordeelname te verkry, sluit Hansie die hanslam aan by Fourie se gebruik van epiese tegnieke in sy volwassenedramas. Daarvan is die opvallendste die aansluiting by Die koggelaar (1988), waarin daar ook 'n "aangenome mens" ("skaap") voorkom, naamlik Knaplat.

\section{'n Verbeeldingswêreld word geskep: meisie- en bendedramas}

In nog 'n groep kinderdramas kom fantasie- en magiese elemente tot uiting in ' $n$ sterk verbeeldingswerklikheid. Daarvan is meisiedramas en bendedramas, dikwels met 'n spook- of avontuurtema, 'n voorbeeld.

Eunice Bosman se werk Eikenhof se spookvrou (1952) se subtitel is "'n toneelstuk vir dogters". Daarin vertel Ralie aan haar koshuisvriendinne 'n spookstorie, maar Susan en Hetta glo haar nie. Hulle aanvaar die uitdaging om middernag na die kunslokaal te gaan waar dit glo spook. Nadat die dogters haar toegetakel het, blyk dit egter dat die "spook" die skoolhoof is. 'n Soortgelyke teks maar met 'n gewelddadiger slot, is Marietjie Pretorius se Kinderspeletjies (1990), waarin Vanessa O'Kennedy deur haar vriendinne opgehang word. In 
Ettie Bierman se seunsdrama Die Swartkat-bende vang 'n skelm (1969) dra elemente van 'n bendekultus by tot die verbeeldingselement. Die Swartkatbende dra tydens vergaderings maskers en mantels en maak van 'n geheime kode gebruik.

\section{Herhaaldelik opgevoer}

'n Hele aantal kinder- en jeugdramas wat in die vyftigerjare geskryf, opgevoer of gepubliseer is, is in die dekades daarna herdruk en by herhaling opgevoer. So 'n stuk is Hélène Pienaar-De Klerk se In 'n ou Kaapse tuin, wat vir die eerste keer opgevoer is as deel van die Kindertoneelfees in Kaapstad tydens die Van Riebeeckherdenking in 1952 en in 1961 gepubliseer is (Nasionale Toneelbiblioteek, 1986:13, 30).

In 'n ou Kaapse tuin speel in 1760 af en daarin vertel Nênna, 'n bejaarde slavin, hoe sy toe sy nog as Ayèsja bekend gestaan het, van haar eienaar af weggeloop het. Primêre en sekondêre werklikhede skuif tydens die opvoering in die vorm van terugflitse oormekaar. Die beeldjie wat haar gehelp het om haar vryheid te verkry, verskyn en verdwyn op die verhoog. Die optrede van die Silwerblaarboodskappertjies, wat op versoek van die beeldjie silwer blare laat val om die verdwaalde kinders terug te lei, dra tot dié sprokies- en fantasie-element by.

Die relatiewe hoogbloei wat die Afrikaanse kinder- en jeugtoneel in die dekade van sestig beleef het, het die publikasie van enkeltekste, soos Pienaar-De Klerk se In 'n ou Kaapse tuin, vergemaklik. Vanaf die sewentigerjare het die posisie van hierdie vorm van Afrikaanse toneel binne die Suid-Afrikaanse teatersisteem egter toenemend verswak.

\subsection{Tendense in kinder- en jeugdramas ná die sestigerjare}

\section{Grensoorskryding}

Die Afrikaanse kinder- en jeugdrama deel met prosawerke ná die sestigerjare 'n aantal grensoorskrydings. In die geval van kinder- en jeugdramas wat na ongeveer 1960 opgevoer of gepubliseer is, het verskillende tipes grensoorskrydings (van byvoorbeeld tema of genre) daartoe aanleiding gegee dat die sisteem self vernuwe. Grensoorskrydings in kinder- en jeugdramas gaan dikwels saam met sosiale veranderings.

Die aard van hierdie oorskrydings tree duidelik na vore indien ' $n$ mens ' $n$ vergelyking tref tussen die grondstof in De Waal (Janni, 
1942:20-25) se 'n Les oor di tier en 'n aantal dramas wat na 1960 gepubliseer is.

In 'n Les oor di tier teken Meester 'n tier op die bord en skryf die woord "tier" as inleiding tot die les daaronder neer. Eers moet hy die orde herstel onder sy uitbundige leerlinge, wat die klas behoorlik op horings neem. Die Engelse invloed op die personasies se taalgebruik is opvallend in die dialoog. Meester sê byvoorbeeld vir Piet: "Staan jij nou bottom [agter]!" Kindersleng, soos dit vandag bekend is, kom egter nog nie voor nie.

'n Eeu later maak De Waal se sorgelose, stoeiende skoolkinders in Hennie Aucamp se werk Die rooi bal (1991) plek vir 'n rystoelgekluisterde Henkie. In die drama vlieg 'n rooi bal oor die muur en Faried beveel Henkie om 'n paar treë te loop. Wanneer die inwonende verpleegster terugkeer, is daar egter geen teken van Faried, sy suster Zubayda of van 'n rooi bal nie en staan die koek wat Faried sou saamgeneem het, nog steeds op die tafel.

Grensoorskrydings in die Afrikaanse kinder- en jeugdrama is nie so dramaties as in Afrikaanse prosawerke nie (vergelyk die oorsig in Fairer-Wessels \& Van der Walt, 1999:95-105).

\section{Maatskaplike probleme as tematiese grensoorskryding}

'n Vroeë voorbeeld van 'n jeugdrama wat tematies grensoorskrydend was, is W.A. de Klerk se Die end van die reënboog (1953) waarin die gevolg van hul ouers se egskeiding op die susters Jeanne en Marie van Dijl voorgestel word. Verwante temas in prosawerke uit die negentigerjare wat tot dramas verwerk is, sluit by die tema van egskeiding aan. ' $n$ Voorbeeld is Lizz Meiring se verwerking van Barrie Hough se prosawerk Vlerkdans, wat in 1999 tydens die Aardklop Nasionale Kunstefees op Potchefstroom opgevoer is. 'n Resensent (Booyens, 1999:14) beweer dat dié stuk "'n belangrike mylpaal en waterskeiding is vir kontemporêre Afrikaanse jeugteater".

Vlerkdans sluit aan by sake soos vigs, tienervriendskap, dwelmmisbruik en die mens se vermoë om pyn deur die bemiddeling van kuns te verwerk. Vlerkdans bied egter ook oorskrydings van genreén tematiese grense.

\section{Genre en tematiese grense word oorskry}

Tekste in Temple Hauptfleisch se bundel Die magiese kring (1994) verteenwoordig weer oorskrydings van konvensies geassosieer met die allegorie (Sandra Dippenaar se Die glaswiel), anekdote (Hennie 
Aucamp se Vyf blikkies boeliebief) en melodrama (C.M. du Toit se Die skuld van Sarel Sluim).

Nog gepubliseerde voorbeelde van die oorskryding van genregrense is Ernest A. Loth se teks Eendag is daar: ('n Sprokie vir Grootmense) (1991) en Kobus Strydom se kabaret Hoe's dit, my ou? (1989). Soos blyk uit die opskrifte by die onderafdelings hiervan, word oorskrydings binne die ontwikkelingsgeskiedenis van die Afrikaanse kinder- en jeugdrama veral tematies verder gevoer in Hoe's dit my ou?

In Hoe's dit my ou? moet die afdeling "Selfvernietiging" volgens die neweteks in die styl van die mime gespeel word. In Vra vir Ma, vra vir Pa wil Jannie weet: "Nou Pa, waar kom ek vandaan, hê Pa?", terwyl "Selfmoord" begin met "As ons hierdie miergif drink, sal ons nie weer terugkom nie, Sus." Ander opskrifte is "Matriekmakietie" (oor voorkoms en die siekte anorexia nervosa) en "Uitgebom", met die strofe:

Morpheus, god van drome, seun van slaap.

Jy't gekom, versteek in 'n poeier, opgevang in 'n spuit.

\section{Politieke allegorie}

Loth se sprokie vir grootmense, Eendag is daar (1991) is 'n voorbeeld van 'n politieke allegorie na die aard van George Orwell se Animal Farm (1945). As gevolg van 'n naderende storm word Rooikappie, Prins, Swart Vark, Bruin Vark en Wit Vark gedwing om by Sneeuwitjie in haar "sprokiesagtige huis in 'n woud" skuiling te gaan soek. Dit noop Swart Vark om oorstelp uit te roep: "Wil jy nou meer! 'n Regte reünie!" Kort voor lank begin die varke onder mekaar stry, sodat Prins - die wolf in vermomming - hulle moet vermaan:

Julle Varke moet nou end kry met julle nonsens. Julle is al drie Varke van enerse pootjies, of jy nou 'n Swart Vark is, 'n Bruin Vark of 'n Wit Vark. Dit staan soos 'n paal bo water: julle sal julle balke moet vat, jul strooi en julle stene en één groot huis moet bou en daar saamwoon ... waarom moet julle apárt bly?

\section{Multikulturaliteit en inheemse folklore}

Ander kinder- en jeugdramatekste het die Afrikaanse letterkunde verruim deur hul voorstelling van multikulturaliteit en inheemse folklore. 
In Renier van Loggerenberg se Die grot en die smokkelaars (1994) ontdek 'n groep seuns "'n sak vol goeters" voor 'n grotopening en raak dan deurmekaar met twee smokkelaars, Pap en Wors. Die idee van multikulturaliteit word gesuggereer deur die samestelling van die groep. Tog is die teks deurgaans in Afrikaans geskryf, al sou Cassim en Sipho se moedertaal nie Afrikaans wees nie. Die grot en die smokkelaars sluit aan by "[a]dventure stories, often featuring both black and white main characters [...]" wat vanaf die sewentigerjare in jeugprosawerke deur skrywers, so uiteenlopend soos John Coetzee, Pieter Pieterse of Peter Slingsby, begin verskyn het (Tötemeyer, 1993:168).

Elise van Wyk maak in Die boomvrou (1994) en Martie Preller in Die legende van die slang en die kind (1994) in Afrikaans van aspekte van inheemse folklore gebruik. Preller verleen aan haar teks outensiteit deur van groetvorme soos "Hambana, Manana" gebruik te maak en na die slang te verwys as 'n "nyoka".

\section{Stadsbestaan, wetenskapsfiksie}

Nog opvallende temas in die Afrikaanse kinder- en jeugdrama na 1960 hou verband met die stadsbestaan van kinders, in teenstelling met ' $n$ vroeëre landelike beeld (Temple Hauptfleisch se Boomhuis, droomhuis, 1985). Daarby sluit tekste aan wat as wetenskapsfiksie kan deurgaan, soos Yslik baie oeslak (1994) deur De Waal Venter, of De Bruyn se brein (1993) deur Braam van der Vyver.

\section{Ten slotte}

Indien 'n mens die invloede óp en die tendense ín toneel vir volwassenes vanaf ongeveer 1922 met dié in kinder- en jeugtoneel vergelyk, toon kinder- en jeugtoneel opvallende ooreenkomste met toneel vir volwassenes. Dieselfde sosiale, politieke en ekonomiese faktore het op verskillende vlakke grensoorskrydend op kinder- en jeugtoneel ingewerk. In hierdie verband verteenwoordig die sewentigerjare 'n keerpunt. 7

7 In toneel vir volwassenes het die werklike keerpunt egter eers in 1983 met die instelling van Kampustoneel gekom. Alhoewel jeugteater tydens Kampustoneelfeeste opgevoer is, was kinder- en jeugteater nie die fokus van hierdie geleenthede nie. 
Soos in prosawerke vir die jeug is ' $n$ uitsondering die voorstelling van die Suid-Afrikaanse Oorlog as tema 'n eeu na die gebeurtenis.8 Alhoewel die Suid-Afrikaanse Oorlog as tema in dramas vir volwassenes voorgekom het, byvoorbeeld in ongepubliseerde tekste deur Nico Luwes (Skroot) of Charles J. Fourie (Die papegaaivrou), is nie een teks met hierdie tema gepubliseer nie. Publikasie sou in 'n tyd wat Afrikaanse dramatekste slegs by uitsondering gepubliseer word, as 'n aanduiding van die 'kanoniseerbaarheid' van so 'n teks gedien het.

Fleishman (2001:98) wys in hierdie verband daarop dat die SuidAfrikaanse toneel vanaf die negentigerjare 'n "theatre of smaller narratives" geword het, "which is more personal, more introspective, more reflective of the ambiguities and contradictions which are at the heart of our new society". Op dieselfde plek verduidelik hy dat die toneel in daardie tyd na sy gemeenskapswortels begin terugkeer het, naamlik "tuning into its environment and its specific community".

In toneelstukke vir volwassenes het die terugkeer na gemeenskapswortels tydens kunstefeeste vorm begin aanneem. Vir Hauptfleisch (2001:172) is die Klein Karoo Nasionale Kunstefees se aard en inhoud hoofsaaklik Afrikaans. Kinder- en jeugtoneel het egter nie tydens hierdie feeste dieselfde reikwydte as toneel vir volwassenes getoon nie, soos blyk uit die direkteur van die Stellenbosch Woordfees se opmerking dat daar "nog nie deurgaans genoeg by kultuurfeeste in die algemeen voorsiening gemaak [word] vir voorskoolse kinders en die jeug nie" (Van Zyl, 2004).

\section{Geraadpleegde bronne}

BINGE, L.W.B. 1969. Die ontwikkeling van die Afrikaanse toneel (1832 tot 1950). Pretoria: Van Schaik.

BOOYENS, H. 1999. 'n Mylpaal en waterskeiding vir die Afrikaanse jeugteater. Beeld: 15, Maart 14.

Hoe min aandag die Suid-Afrikaanse Oorlog toe in Afrikaanse jeugprosa ontvang het, blyk onder andere uit die volgende opmerking deur Van der Walt (2001:546): "Hoewel die geskiedenis van die Afrikaanse kinderliteratuur relatief kort is en dit in werklikheid maar eers sedert die vyftigerjare 'n opbloei getoon het [...], is dit tog opvallend dat daar relatief min kinderboeke met die oorlog as tema verskyn het. In teenstelling met die fiksie vir volwassenes het die herdenking van die oorlog tot aan die einde van 2000 nog geen nuwe Afrikaanse kinderboeke tot gevolg gehad nie. Daar het trouens sedert 1990 nie een nuwe Afrikaanse kinderboek verskyn met die oorlog as tema nie." 
BOSMAN, F.C.L., red. 1942. Di bedriegers, Magrita Prinslo, en ander Afrikaanse dramas en samesprake tot 1900. Johannesburg: Voortrekkerpers. (Uitgawe van die Patriot-Vereniging vir Afrikaanse Teksuitgawes, nr. 5.)

BOSMAN, F.C.L. 1968. Historiese oorsig van die Afrikaanse drama. (In Bosman, F.C.L. Vier uitgesoekte eenbedrywe. Johannesburg: Afrikaanse Pers Boekhandel. p. 1-27.)

DAVENPORT, T.R.H. 1989. South Africa: a modern history. Bergvlei: Southern.

DE KOCK, D.M. 1987. Drama-in-die-onderwys as onderwysstrategie. Pretoria: Universiteit van Pretoria. (M.A.-verhandeling.)

FAIRER-WESSELS, F. \& Van der Walt, T. 1999. Temas en tendense in hedendaagse kinderliteratuur. Stilet, 11(1):95-105.

FLEISHMAN, M. 2001. Unspeaking the centre: Emergent trends in South African theatre in the 1990s. (In Kriger, R. \& Zegeye, A., eds. Culture in the new South Africa: After Apartheid. Vol. 2. Cape Town/Maroelana: Kwela/SA History Online. p. 91-115.)

GHESQUIERE, R. 1995. Het verschijnsel jeugdliteratuur. Leuven: Acco.

GREYVENSTEIN, W.R. 1988. The history and development of children's theatre in English in South Africa. Johannesburg: RAU. (D.Litt. et Phil. thesis.)

GREYVENSTEIN, W.R. 1989. Let us entertain you! Children's theatre and popular entertainment. South African Theatre Journal, 3(2):51-90.

HAUPTFLEISCH, T. 2001. The eventification of Afrikaans culture - some thoughts on the Klein Karoo Nasionale Kunstefees (KKNK). South African Theatre Journal, 15:169-176.

HUNT, P. 1991. Criticism, theory, and children's literature. Oxford: Blackwell.

ISKEMUS [Inligtingsentrum vir Kinderlektuur en -Media van die Universiteit van Stellenbosch]. s.j. Applous! Toneelstukke vir die primêre skool: 'n kort, geselekteerde bibliografie. Stellenbosch: Die Inligtingsentrum.

JANNI (ps. De Waal, J.H.H.). 1942. 'n Les oor di tier. (In Bosman, F.C.L., red. Di bedriegers, Magrita Prinslo, en ander Afrikaanse dramas en samesprake tot 1900. Johannesburg: Voortrekkerpers. p. 20-25.) (Uitgawe van die Patriot-Vereniging vir Afrikaanse Teksuitgawes, nr. 5.)

KANNEMEYER, J.C. 1981. Inleiding. (In Kannemeyer, J.C., samest. Uys Krige: vier eenbedrywe. Pretoria: Van Schaik. p. 1-20.)

LE ROUX, J. DE V. 1986. 'n Kort oorsig van die geskiedenis van die Afrikaanse kinderliteratuur. (In Hölscher, Marianne., red. Doer-land-y: Suid-Afrikaanse geïllustreerde kinderboeke. Kaapstad: Suid-Afrikaanse Nasionale Kunsmuseum. p. 4-10.)

LOHANN, C. 1988. Historiese oorsig oor die Afrikaanse kinderboek. (In Cilliers, I., red. Op weg na begrip: kinderliteratuur vir Suider-Afrika. Kaapstad: Miller/Longman. p. 184-189.)

LOMBARD, C.J. 1974. 'n Ondersoek na die jeugtoneel met betrekking tot die eietydse adolessent. Stellenbosch: Universiteit van Stellenbosch. (M.A.verhandeling.)

LOUW, C. 1965. Kindertoneel. Klerksdorp: Voortrekkerpers.

NASIONALE TONEELBIBLIOTEEK. 1986. Katalogus van kindertoneelstukke. Bloemfontein: Openbare Biblioteek.

NASIONALE TONEELBIBLIOTEEK. 1987. Byvoegsel tot Katalogus van kindertoneelstukke. Bloemfontein: Openbare Biblioteek. (No. 1.) 
NASIONALE TONEELBIBLIOTEEK. 1988. Byvoegsel tot Katalogus van kindertoneelstukke. Bloemfontein: Openbare Biblioteek. (No. 2.)

NASIONALE TONEELBIBLIOTEEK. 1992. Byvoegsel tot Katalogus van kindertoneelstukke. Bloemfontein: Openbare Biblioteek. (No. 3.)

NASIONALE TONEELBIBLIOTEEK. 1994. Byvoegsel tot Katalogus van kindertoneelstukke. Bloemfontein: Openbare Biblioteek. (No. 4.)

NASIONALE TONEELBIBLIOTEEK. 1999. Ongepubliseerde manuskrip: Byvoegsel tot Katalogus van kindertoneelstukke. Bloemfontein: Openbare Biblioteek.

SENEKAL, J. \& VAN ASWEGEN, K. 1980. Bronne by die studie van Afrikaanse dramas 1900-1978. Johannesburg: Perskor.

STEENBERG, E. 1983. Waar staan ons kindertoneel? Klasgids, 18(3):12-16.

STEENBERG, E. 1985. Bekende kinderverhale in toneelgedaante. Klasgids, 20(1):3-6.

STEENBERG, E. 1987. Fantasie en die kinderboek - 'n kernhandleiding. Pretoria: HAUM-Literêr.

STORRAR, P. 1968. Beginners please: a history of The Children's Theatre in South Africa. Johannesburg: Board of Directors of The Children's Theatre.

TÖTEMEYER, A-J. 1993. Trends in children's literature at home and abroad. (In Cilliers, I., ed. Towards more understanding: The making and sharing of children's literature in Southern Africa. Cape Town: Juta. p. 159-169.)

VAN DER WALT, T.B. 2001. Die Anglo-Boereoorlog in Afrikaanse kinderboeke. Johannesburg: RAU. (D.Litt. et Phil.-proefskrif.)

VAN RYSWYK, E. 1985. Voorwoord. (In Uys, P. Skote! Johannesburg: Perskor. p. i-iii.)

VAN TONDER, K., samest. s.j. Applous: Afrikaanse dramas vir tieners, 19731989. Stellenbosch: ISKEMUS.

VAN ZYL, D. 2004. Feeste en toneel: 'n fennootskap [sic] wat werk. http://www.litnet.co.za/teaterindaba/dorothea.asp [6 Jan. 2005].

\section{Kernbegrippe:}

geskiedenis van kinder- en jeugtoneel in Afrikaans

oorsig van kinder- en jeugtoneel in Afrikaans

tendense in kinder- en jeugtoneel in Afrikaans

\section{Key concepts:}

history of Afrikaans children's and youth theatre overview of Afrikaans children's and youth theatre trends in Afrikaans children's and youth theatre 
